\title{
Enhanced composting as a way to a climate-friendly management of coffee by-products
}

\author{
Macarena San Martin Ruiz ${ }^{1} \cdot$ Martin Reiser $^{1} \cdot$ Martin Kranert $^{1}$ \\ Received: 11 November 2019 / Accepted: 2 April 2020 / Published online: 18 April 2020 \\ (C) The Author(s) 2020
}

\begin{abstract}
This study investigated the performance of aerobic windrow systems by using coffee by-products and green waste to reduce gaseous emissions. Thereafter, a comparison with the current treatment and gaseous emissions at a Coffee Mill in Costa Rica was made. Two different studies where performed in Germany (pile I and II) and one study in a Coffee Mill in Costa Rica (pile III). Temperature, water content, and $\mathrm{pH}$ were the key parameters controlled over 35 days in all the systems. Moreover, $\mathrm{CH}_{4}$ emission rates were quantified by a FTIR and by a portable gas detector device where the emissions reached values 100 times higher when coffee by-products as a unique material for the composting process was used. Results show that highest emission rates during the composting process for pile I was $0.007 \mathrm{~g}\left(\mathrm{~m}^{2}\right)^{-1} \mathrm{~h}^{-1}$, for pile II $0.006 \mathrm{~g}\left(\mathrm{~m}^{2}\right)^{-1} \mathrm{~h}^{-1}$, and for pile III $3.1 \mathrm{~g}\left(\mathrm{~m}^{2}\right)^{-1} \mathrm{~h}^{-1}$. It was found that $\mathrm{CH}_{4}$ emissions could be avoided if the mixture and the formation of the windrow piles were performed following the key parameter for composting, and the usage of additional material is used. With this, the reduction of $\mathrm{CH}_{4}$ emissions at the Mill in Costa Rica could be achieved in the future.
\end{abstract}

Keywords Composting $\cdot$ Coffee by-products $\cdot$ Coffee pulp $\cdot$ Methane $\cdot$ Emission rates $\cdot$ Greenhouse gases

\section{Introduction}

Composting among the years has become a promising natural way of recycling organic matter and producing fertilizer under low operating costs and minimal technology (Haug 1993; Misra et al. 2003). It is defined as "a biological decomposition and stabilization of organic substrates, under conditions that allow the development of thermophilic temperatures as a result of biologically produced heat, to produce a final product that is stable, free of pathogens and plant seed and can be beneficially applied to land" (Artola et al. 2015; Misra et al. 2003). The base of composting is not the complete decomposition of the input components but rather to prepare a biologically stable material which is not exposed to a process of rapid decomposition or undesirable rotting (Burg et al.

Responsible Editor: Philippe Garrigues

Macarena San Martin Ruiz

macarena.sanmartin@iswa.uni-stuttgart.de

1 Institute for Sanitary Engineering, Water Quality and Solid Waste Management, University of Stuttgart, Bandtäle 2,

70569 Stuttgart, Germany
2011). During the process, temperature has been one key factor in composting which has been used as a tool to follow the degree of stabilization as a result of microbial activities during the process (Bueno et al. 2007). One of the disadvantages of composting is the formation of greenhouse gases (GHG) such as methane $\left(\mathrm{CH}_{4}\right)$ that enhance the global warming ( $\mathrm{Zhu}-$ Barker et al. 2017). The GHG formation occurs from the activity of microorganisms during the composting process (Sun et al. 2014). $\mathrm{CH}_{4}$ corresponds to the main product when the windrow piles do not receive the necessary oxygen at the core of the windrow (Amlinger et al. 2008). In the agricultural sector, GHG represents $24 \%$ of the total emissions globally, excluding carbon dioxide $\left(\mathrm{CO}_{2}\right)$ since the gas generated is climate-neutral carbon, for the reason that it originate from the conversion of organic material and dead organic matter (Amlinger et al. 2008; Sun et al. 2014).

Currently, the Mill of study in Costa Rica is treating its coffee residue to produce compost, where the main material is based on coffee husk and coffee pulp (Fig. 1) as coffee byproducts (Zarrinbakhsh et al. 2016).

During the wet process of coffee bean extraction, these coffee by-products are divided into coffee husk, skin, pulp, mucilage, and parchment (Esquivel and Jiménez 2012; Iriondo-DeHond et al. 2019). The main coffee by-product 
obtained during wet or semi-dry processing is the coffee pulp, which corresponds to approximately $29 \%$ on a dry-weight basis (Blinová et al. 2017; Heeger et al. 2017), where one ton of coffee pulp is generated for every two tons of green coffee produced (Esquivel and Jiménez 2012). Coffee pulp is an organic waste that contributes to pollution and environmental problems when the coffee berries are ripe and processed during the wet method (Lardé 1989; Blinová et al. 2017). In each harvest at this Mill in Costa Rica, where wet process is the main method to process the coffee cherries, the coffee byproducts produced are approximately $37,000 \mathrm{Mg} /$ year.

Understanding greenhouse gas emissions formation is an important criterion in future evaluation options for climate change mitigation within the coffee sector (Rahn et al. 2014; Nieters et al. 2015). Coffee by-products are also the contributors to climate change as a result of their greenhouse gases emitted (Rahn et al. 2014); therefore, their emissions play an important role.

In this study, first a characterization of coffee byproducts and green waste products was completed. Based on this, it was proposed to carry out a pilot plan in Germany with different green waste materials and coffee pulp to investigate the behavior of this coffee by-product during the composting process for 35 days. In addition, to determine the capacity to reduce greenhouse gases emissions and other harmful impacts on the environment, a comparison with the current composting process at the Mill in Costa Rica and the composting process which was performed in Germany were made.

Finally, the quantification of $\mathrm{CH}_{4}$ emission rates in three different piles containing coffee pulp as a main component was performed to analyze the relevance of external materials and their relationship with the current $\mathrm{CH}_{4}$ emissions within the usage of coffee pulp during composting.

\section{Materials and methods}

\section{Windrows description}

Composting profile, chemistry, and greenhouse gas emissions were monitored at the composting plant facility in Germany and at the Mill in Costa Rica. The coffee pulp was sundried at the Mill and shipped to Germany. Once it arrived in Germany, naturally the material was humidified until the fresh percentage that the fruit possess. On the other hand, the green waste for the experimental site in Germany was obtained from the composting plant facility where the windrows were built. Three windrow piles were monitored in total, and the main component was the coffee by-product.

The first pile (I) was formed using $50 \%$ based on volume of coffee pulp, a mixture of $50 \%$ based on volume of green waste, and a structural material at the composting plant facility during the winter season. Pile II was formed using $20 \%$ more based on volume of coffee pulp than in pile I, a mixture of $30 \%$ based on volume of green waste, a and structural material composted during the spring season, whereas pile III was completely made with coffee by-products during the summer season using the current methodology of the mill at the Mill in Costa Rica. Two windrows piles (I and II) were monitored in Germany and afterwards compared with the current emissions obtained from a previous study (San Martin Ruiz et al. 2018).

The piles were running for a period of 35 days, taking into account the specifications at the composting plant facility to produce compost using green waste material as an input. The material was turned weekly using a Tracturn ${ }^{\circledR}$ windrow turner at the composting plant facility and in Costa Rica with a Backhus ${ }^{\circledR}$ windrow turner. The sizes of the piles in Germany were approximately $6 \mathrm{~m}^{3}$, while in Costa Rica, the pile was approximately $90 \mathrm{~m}^{3}$ with $1.2 \mathrm{~m}$ high and $2.2 \mathrm{~m}$ wide for all the piles.

Table 1 Constituents of input material for each windrow pile

\begin{tabular}{|c|c|c|c|c|c|c|c|c|}
\hline Windrow system & Material & $\mathrm{C} / \mathrm{N}$ & $\mathrm{pH}$ & $\kappa \mathrm{mscm}^{-1}$ & $\mathrm{WC} \%$ & DS $\%$ & ${ }_{t} g / L$ & VS $\%$ \\
\hline \multicolumn{9}{|c|}{ Input material Germany } \\
\hline I and II & Humidified coffee pulp & $20 \pm 0.2$ & $6 \pm 0.1$ & $1.1 \pm 0.1$ & $79.7 \pm 0.2$ & $20.3 \pm 0.2$ & $564 \pm 6.0$ & $90.9 \pm 0.4$ \\
\hline I & Green waste $^{1}$ & $22 \pm 0.1$ & $5 \pm 0.1$ & $2.0 \pm 0.4$ & $21.3 \pm 0.2$ & $78.7 \pm 0.3$ & $505 \pm 5.0$ & $98.1 \pm 0.1$ \\
\hline I & Structure material $^{2}$ & $28 \pm 0.3$ & $6 \pm 0.1$ & $0.9 \pm 0.1$ & $25.8 \pm 0.2$ & $74.2 \pm 0.1$ & $232 \pm 3.0$ & $67.8 \pm 1.3$ \\
\hline II & Structure material ${ }^{3}$ & $67 \pm 0.5$ & $6 \pm 0.1$ & $0.4 \pm 0.3$ & $31.8 \pm 1.2$ & $68.2 \pm 0.8$ & $190 \pm 5.0$ & $77.2 \pm 0.1$ \\
\hline II & Green waste $^{4}$ & $31 \pm 0.1$ & $7 \pm 0.2$ & $0.7 \pm 0.2$ & $35.8 \pm 0.0$ & $64.2 \pm 0.5$ & $550 \pm 5.0$ & $53.6 \pm 0.2$ \\
\hline \multicolumn{9}{|c|}{ Input material in Costa Rica } \\
\hline III & Fresh pulp & $13.4 \pm 0.2$ & $3.9 \pm 0.1$ & $1.6 \pm 0.1$ & $84.9 \pm 0.2$ & $15.1 \pm 0.7$ & $600 \pm 10.0$ & $88.9 \pm 1.8$ \\
\hline
\end{tabular}

1,2: Green waste and structural material during winter season in Germany

${ }^{3,4}$ Green waste and structural material during spring season in Germany

Standard deviation of the mean values $n=3$ for all the values 
Gas samples were collected weekly before each turning event. Compost samples were collected before and after each turning event. Temperature was measured continuously using an Armatherm thermometer® T-logger in pile I and II. On the other hand, at the Mill, the temperature was measured twice a day during the mornings and afternoons using a compost thermometer and the samples for the key parameters where collected weekly.

\section{Compost sampling and analyses}

Compost input material which was used to form the windrow piles in Germany were sampled to quantify the gravimetric water content (WC), $\mathrm{pH}$, electrical conductivity $(\kappa)$, bulk density $(\mathrm{t})$, dry solids (DS), volatile solids (VS), and carbon to nitrogen $(\mathrm{C} / \mathrm{N})$ ratio which are shown in Table 1. Once the windrow piles were formed, $\mathrm{WC}, \mathrm{pH}$, and $\mathrm{C} / \mathrm{N}$ ratio were performed weekly. The samples were collected before and after each turning event and were taken from 5 different locations and depths along the pile to obtain a representative sampling over the entire pile. Water content was calculated from field moist and oven-dry $\left(105^{\circ} \mathrm{C}\right.$ for $\left.48-72 \mathrm{~h}\right)$ mass of compost according to the DIN EN 13040 (BGK 2017). The $\mathrm{pH}$ was extracted from $20 \mathrm{~g}$ (wet weight) of compost with $180 \mathrm{~mL}$ of $\mathrm{CaCl}_{2}$ and assessed by potentiometric measurements.

Electricity conductivity was extracted from $20 \mathrm{~g}$ (wet weight) of compost with $180 \mathrm{~mL}$ of distillated water. Volatile solids were performed and calculated according to the Federal Compost Quality Assurance Organization (FCQAO) (Bidlingmaier 2003) and according to the DIN 18128. C/N ratios were performed using a vario Max CN element analyzer GmbH® following the DIN ISO 10694.

For the VS, three replicates of $10 \mathrm{~g}$ were inserted into a porcelain crucible with known weight. The samples were inserted into a furnace at $550{ }^{\circ} \mathrm{C}$ and burned until constant weight according to the DIN 18128. Thereafter, the volatile solids were calculated for each replicate, and the average of the three values was taken to represent the organic content of the sample.

\section{Gas measurements and collection}

At the composting plant facility in Germany, an open upper part chamber was placed on top of the windrow piles and inserted approximately 5-10 cm deep into the windrow to seal the chamber against atmospheric influences in order to quantify the windrow emissions focusing on $\mathrm{CH}_{4}$ measurements. At each sampling event, the sample was taken from at the top of the windrow

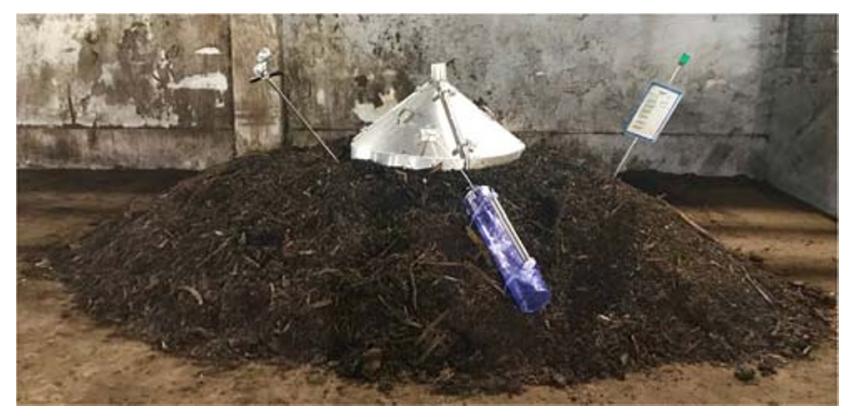

Fig. 1 Gas measurement at the composting plant facility

pile since the main emissions are emitted at this area of the pile (Ahn et al. 2011).

During sampling, the flow principle passing through the sampling hood at a passive area source was used to extract a defined amount of air (open upper part chamber), covering the entire area required for sampling as a function of the constant flow of emissions and supply of ambient air (Bidlingmaier 2003; VDI 3475 part 2 2005). The sampling device consists of a vacuum vessel which is discharged by using a vacuum pump, and at the same time, a hose is connected between the open upper part chamber and the vacuum vessel to collect the gas.

When the sampling device begins pumping, the sampling bag, made of Nalophan, absorbs the inner gas (Fig. 1). The upper part was uncovered allowing the ambient air to enter and to be mixed inside of the sampling hood. The gas collection was done weekly for a period of $30 \mathrm{~min}$ in order to collect $6 \mathrm{~L}$ of gas in a sampling bag. The gas samples were analyzed using Fourier-transform infrared spectroscopy (FTIR). Thereafter, the gas measurements were compared according to the previous study performed at the Mill in Costa Rica, where an open upper part sampling hood was used to measure the gas concentration by using a portable gas detector device (Fig. 2) (San Martin Ruiz et al. 2018).

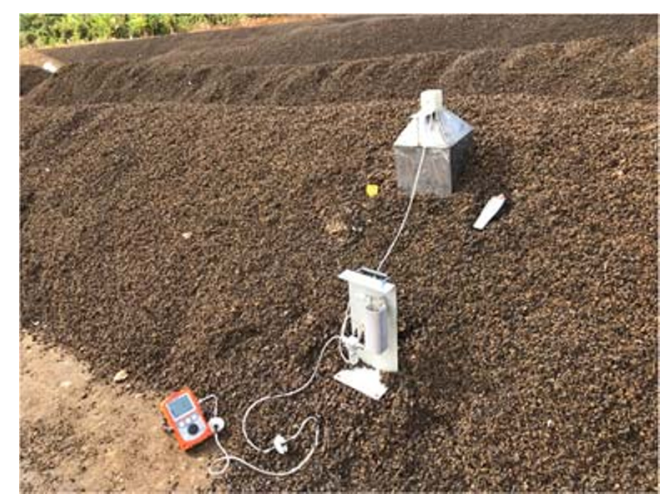

Fig. 2 Gas measurement at the Mill in Costa Rica 


\section{Emission rates}

The emission rates were calculated according to the sampling chamber volume, sampling chamber area, flow volume of the measurement equipment, and a specific flow rate each measurement performed. The following equations describe the calculations and formulas used to obtain the emission rates (Clauß et al. 2019; San Martin Ruiz et al. 2018).

$\mathrm{C}_{\mathrm{CH} 4}=\left(\mathrm{M}_{\mathrm{CH} 4} * \varphi_{\mathrm{CH} 4}\right) / \mathrm{V}_{\mathrm{mo}} 1$

$\mathrm{C}_{\mathrm{CH} 4}$ : methane concentration, $\left(\mathrm{mg} / \mathrm{m}^{3}\right)$

$\mathrm{M}_{\mathrm{CH} 4}$ : molar mass of methane, $(\mathrm{g} / \mathrm{mol})$

$\mathrm{V}_{\text {mo }}$ : $22.4139 \mathrm{~L}$ at standard conditions

$\varphi_{\mathrm{CH} 4}$ : methane in volume percentage or in $\mathrm{ppm}$.

For Emission rates:

$\mathrm{q}_{\mathrm{CH} 4}=\left(\mathrm{C}_{\mathrm{CH} 4} * \mathrm{~V}_{\text {gas }}\right) / \mathrm{A}_{\mathrm{H}}$

$\mathrm{q}_{\mathrm{CH} 4}$ : emission rate of methane, $\left(\mathrm{g} / \mathrm{m}^{2} \mathrm{~h}\right)$

$\mathrm{C}_{\mathrm{CH} 4}$ : methane concentration, $\left(\mathrm{mg} / \mathrm{m}^{3}\right)$

$\mathrm{A}_{\mathrm{H}}$ : hood area, $\left(\mathrm{m}^{2}\right)$

$\mathrm{V}_{\text {gas }}$ : gas flow volume, $(\mathrm{L} / \mathrm{h})$

\section{Statistical analysis}

In total 25 gas measurements during morning and afternoon were performed at the mill in Costa Rica, obtaining up to 5 replicas among the pile. The data for pile III was subjected to one-way analysis of variance ANOVA for Windows. Significant level of $p \leq 0.001$ for pile III was used for all mean
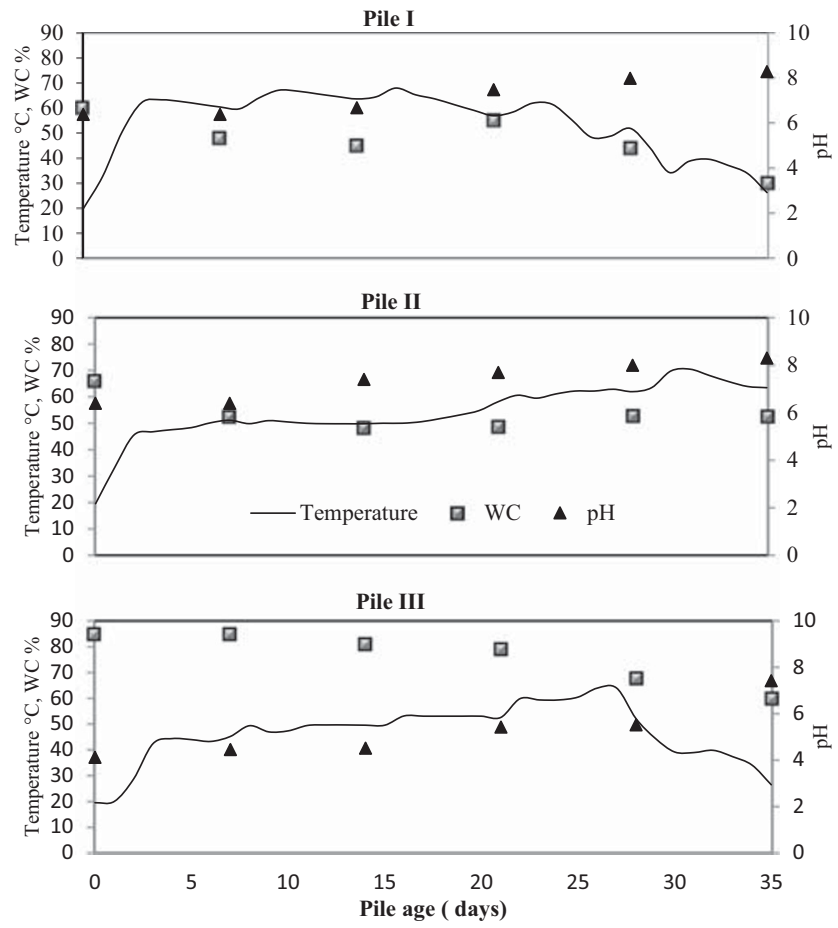

Fig. 3 Temperature, water content concentration, and $\mathrm{pH}$ in three piles values. Meanwhile for piles I and II, measurements were performed once per week. Nevertheless, a $2 \%$ linearity deviation was considered for the results.

\section{Results}

Figure 3 shows a summary of the input features of the compost material measured when the windrows were built. All three piles were having triangular shape, width, and height where the only difference was the length of the pile, and this was due to the viability of coffee pulp material shipped to Germany. Therefore, pile I and II were shorter than at the Mill in Costa Rica. After receiving the dehydrated coffee pulp, certain analyses were carried out to estimate the amount of water necessary to humidify the pulp and with this, to be able to carry out the simulation of fresh material at the composting plant facility in order to follow closely and in a real sense how the coffee by-products are handled at the mill in Costa Rica. As can be seen in Table 1, the hydrated material obtained a difference of 5 percentage point with respect to the percentage of original moisture. $\mathrm{C} / \mathrm{N}$ ratio have increased during the humidification of the coffee pulp, which indicates that during the drying process, the material had a nitrogen transformation; therefore, the $\mathrm{C} / \mathrm{N}$ ratio increased as well as its $\mathrm{pH}$ (Hao and Benke 2008). All the previous analysis indicates that the preliminary results are significant for the study and a comparison between the systems can be made.

\section{Parameters and temperatures profiles in composting windrows}

All the temperature data from the T-logger was given weekly from the personnel of the composting plant facility whereas in Costa Rica, the temperature was measured twice per day (mornings and afternoons). The composting process was performed during different times of the year; therefore, the feedstocks of each pile were based on the available material that the composting plant facility had during that season in addition to the piles experiencing different seasonal conditions. Pile I experienced a winter climate with an average ambient temperature of $5.4{ }^{\circ} \mathrm{C}$. Pile II experience a spring climate season between 13 and $18^{\circ} \mathrm{C}$. Pile III accomplished a summer climate at the Mill in Costa Rica, where the range of ambient temperature was $28{ }^{\circ} \mathrm{C}$ without any rain event. Significant temperature increases were observed between the windrow systems. Pile I and II were performed in a place covered by a roof, while pile III was performed in an open field at the Mill. Generally, the temperature was higher where a high percentage of green waste was added, reaching rapidly $60{ }^{\circ} \mathrm{C}$ within the first week even if the windrow system was performed during winter season and under low ambient temperature. Figure 3 shows that WC decreases among the pile age of 
the windrow systems I and II, whereas in pile III occurred no variation during 20 days of pile age, and the high value is attributed to the high WC of the coffee by-product. It is important to control the degree of degradation during the composting process, because this parameter is used to give information regarding the decomposition process (Burg et al. 2011). Compost microorganisms work best under neutral rather than acidic conditions (Sundberg 2008), where at pH levels under 5, the microorganisms' inhibition can be noticed (Bachert and Wattanachira 2008; Sundberg et al. 2013). Organic acids are neutralized within the process, and mature compost generally has a pH between 6 and 8 (Burg et al. 2011; Sundberg 2008). The pH increased in pile I and II over the pile age, while pile III remained acidic. Pile I and II where carried out under a C/N ratio of 25:1 and 30:1, respectively. The WC in pile I had a rapid evaporation or absorption within the material during this process. No water was added into pile I in order to maintain the humidity from the pile itself. In pile II, the WC was between 30 and $60 \%$ during the pile age, where incorporation of small amounts of water was needed to maintain a WC between 40 and 55\% until the sanitation process occurred. Pile III maintained moisture between 40 and $66 \%$ itself during the total process, and no additional water was added during the process in 35 days.

\section{Methane emissions from compost windrow piles}

All the $\mathrm{CH}_{4}$ emissions were measured before each turning event at the pile in order to achieve the similar conditions for a congruent comparison between the systems. During the conversion of methane concentration to emissions rates (ER), the flow through the upper part chamber was considered. Figure 4 shows the results of emissions rates over the pile age represented in weeks for the three different windrow systems. The emission rates in pile I and II were reduced drastically in comparison with pile III.
However, the pile II had obtained an increase of $\mathrm{CH}_{4}$ emissions in comparison with pile I. This can be related to the amount of coffee pulp increased a $20 \%$. The maximum values of $\mathrm{CH}_{4}$ emission rates in pile I were found during the fourth week, pile II during the third week, and pile III at the first week of composting which can be related to the poor aeration and high WC levels (85\% of WC reported during the first week in pile I), enhancing the methane formation (Amlinger et al. 2008; Hrad et al. 2014; Jenkins 2011; VDI 3475 part 3 2006).

\section{Discussions}

Firstly, the attention was focused on the fact that the amount of green waste and coffee by-product for the composting could be comparable to each other in terms of gaseous emissions and that the additional material would be easily accessible and collected. Therefore, the selection of measurement methods had to allow comparable data in the various types of treatments, as well as $\mathrm{CH}_{4}$ emissions. Temperature profiles show that after increasing the addition of coffee pulp into the windrow pile, the temperature will take up to 25 days to reach the sanitation peak (Diaz et al. 2007; Jenkins 2011).

On the other hand, the temperature at any point depends mainly on the amount of heat produced by microorganisms and the amount lost through aeration and surface cooling. Therefore, the time where the system remains with high temperatures will depend on the chemical composition of the ingredients, as well as the volume of the system. During the thermophilic stage $\left(40-60^{\circ} \mathrm{C}\right)$, the degradation occurs faster and can take from days to months depending on the material and the composition of the ingredients (Cornell University 2001; Sierra et al. 2017; VDI 3475 part 2 2005). This stage of composting contains a relevant path in order to destroy germs that are sensitive to the temperature (Msunar 2009; Sierra et al. 2017; VDI 3575 part 1 2003). In pile I and II,
Fig. $4 \mathrm{CH}_{4}$ emission rates (ER) $\left[\mathrm{g}\left(\mathrm{m}^{2}\right)^{-1} \mathrm{~h}^{-1}\right]$ from the windrow piles plotted with the logarithmic scale to the number of weeks of the process

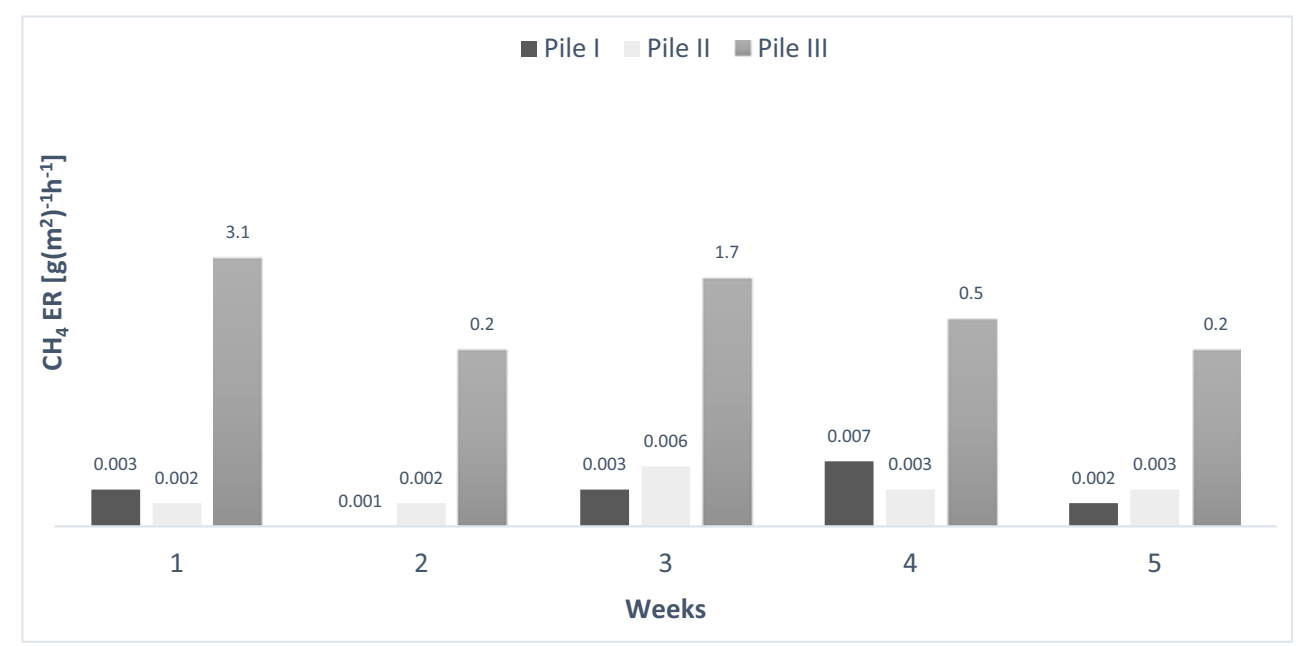


the thermophilic stage starts during the first 2 days of composting, while pile III needed more days to achieve the mesophilic phase. During the first phase of the process, the $\mathrm{pH}$ value tends to drop due to liberation of organic acids.

Thereafter, once the process is moved to the next phases, the $\mathrm{pH}$ value tends to rise since all the organic acids are broken down as well as the alkaline effect of the inorganic salts which tend to be bonded to the organic material. At the end of the phases, the $\mathrm{pH}$ value must fluctuate in the neutral to basic range (Kranert 2017; VDI 3575 part 1 2003).

During the composting process, high temperatures in the windrow pile kill worm eggs and pathogens resulting in a compost sanitation (Bidlingmaier 2003; Federal Compost Quality Assurance Organization 1994; VDI 3475 part 2 2005) which were reached by pile I during the first days of composting whereas in pile II and III after 20 days of composting time. An optimal $\mathrm{C} / \mathrm{N}$ ratio for the development of microorganisms and bacteria responsible for composting is between 25:1 and 40:1 (Ahn et al. 2011). Based on this, the piles at the composting plant facility followed the appropriated ranges of $\mathrm{C} / \mathrm{N}$ during the process.

Three important factors that affect the temperature change are the WC, sufficient oxygen in the windrow pile, and the shape of the pile. The pore-volume relationship during the process is an important prerequisite in order to enhance a good composting process. If the material does not possess enough oxygen and high amount of water content, the low air pore volume in the pile is being affected, and therefore, a release odor due to anaerobic metabolites occur. Triangular shape results in a larger surface-to-volume ratio, giving a natural convection allowing adequate aeration (VDI 3575 part 1 2003). Giving an adequate moisture level, which was given in pile I and II, the microorganism activity is maintained for a longer period. Low water content in the decomposition material may partially or completely inhibit the activity and reproduction rate of the microorganisms (dry stabilization) (Jenkins 2011; VDI 3475 part 2 2005). The recommended WC at the beginning of the windrow pile is $50-60 \%$, finishing the composting process with approximately 30\% (Haug 1993; Misra et al. 2003; Sierra et al. 2017; VDI 3575 part 1 2003). In pile I, the $\mathrm{WC}$ at the beginning was around $60 \%$ and pile II was $66 \%$. Since pile I experienced an early drying process, it was preferable to start with a higher WC value, which after 7 days, the windrow pile had reached the recommended value for the composting process. Pile III, on the other hand, kept a high WC value from the beginning until the last days of pile age. In the case of the coffee pulp, if its water content is comparatively low in porosity below $20-25 \%$ or above $60 \%$, the aerobic process is stopped (Bidlingmaier 2003; Esquivel and Jiménez 2012; VDI 3475 part 3 2006). Above $60 \%$, due to the dense structure of the coffee pulp (Table 1), it tends to keep high moisture content within if the material is not mixed or aerated regularly nor when there is no structural material in the windrow pile. The addition of structural material increases the volume of pore and therefore improves the exchange of water and air (Clausen 2015; Sánchez et al. 2015). Hence, structural material was considered in pile I and II to perform this work. Pile II, for 5 weeks, did not decrease the temperature profile, reaching the sanitation process during the last week, whereas pile III, after 5 weeks, decreased in temperature indicating less microbial activity. Therefore, coffee pulp needs proper $\mathrm{WC}, \mathrm{pH}$, oxygen, and porosity to reach a higher degradation. In addition to temperature measurement, the degradation of organic dry matter showed a rate approximately of $50 \%$ for pile I, $55 \%$ for pile II, and $34 \%$ for pile III.

On the other hand, detection of gaseous emissions is an essential measure for assessing the rotting process in terms of aerobic status and environmental relevance. On this basis, greenhouse gas and odor emissions can be reduced through optimized rotting management. The detection of gaseous emissions during the process of composting coffee byproducts is one of the most important tools to meet the challenge of reducing GHG odor emissions in this sector. Gas concentrations act as indicators of a biological degradation and thus lead to optimization possibilities. Regarding the $\mathrm{CH}_{4}$ emission, previous studies show it is linked to the microorganisms' activity and also connected to $\mathrm{pH}$ and temperature (Zhu-Barker et al. 2017). During the process, pile I and II follow the recommendations and moisture content profile of a proper composting process, while pile III maintains a high WC during the 35 days leading to constant $\mathrm{CH}_{4}$ emissions. It was seen that during the first week, pile III obtained the higher emissions, which might be linked to the amount of water content (85\%), and lack of oxygen due to the compactness of coffee by-product.

During these measurements, the gas measured was $\mathrm{CH}_{4}$ since it is produced and oxidized during the degradation of organic matter with low $\mathrm{O}_{2}$ content and during the biological activity of the windrow pile (Phong and Cuhls 2016). $\mathrm{CH}_{4}$ formation is a product of anaerobic degradation forming organic acids as a result of methanogenesis (Hou et al. 2017; Msunar 2009). Since this gas is formed during endothermic reactions, and also when aerobic piles develope anaerobic zones inside of the pile during the composting process, this gas produce a reduction in the microorganism activity and as a consequence, $\mathrm{CH}_{4}$ emission (Phong and Cuhls 2016; VDI 3475 part 2 2005; VDI 3475 part 3 2006).

It is recommended in order to increase the porosity, oxygen, and decrease of emissions in the pile, the addition of green waste, branches or woodchips into the system, as well as the control of WC and temperature within the process. It was seen in pile III which possessed just coffee by-products, emissions up to 100 times higher than in pile I and II, where green waste and structural material was incorporated to give porosity to the windrow piles at the composting plant facility. 


\section{Conclusions}

Aerobic composting windrows were performed by using coffee by-products as a main component in a composting plant facility and were compared with the current treatment at the Mill, showing better profiles of temperature, $\mathrm{pH}$, and $\mathrm{WC}$ when coffee by-products are mixed with green waste to form windrow piles.

Emission rates were determined and given in $\left[\mathrm{g}\left(\mathrm{m}^{2}\right)^{-1} \mathrm{~h}^{-1}\right]$ based on the methodology described and compared with the emissions at the Mill in Costa Rica. $\mathrm{CH}_{4}$ emission rates were lower in pile I and II than in pile III where the highest emissions rates for 35 days found in pile I was $0.007 \mathrm{~g}\left(\mathrm{~m}^{2}\right)^{-1} \mathrm{~h}^{-1}$, in pile II $0.006 \mathrm{~g}\left(\mathrm{~m}^{2}\right)^{-1} \mathrm{~h}^{-1}$, while in pile III showed an emission of $3.1 \mathrm{~g}\left(\mathrm{~m}^{2}\right)^{-1} \mathrm{~h}^{-1}$.

It was found that $\mathrm{CH}_{4}$ emissions could be avoided if the mixture and the formation of the windrow piles are done following the key parameter for composting, and therefore, the treatment at the Mill have the option to improve and to reduce the GHG emissions, giving the opportunity at the coffee sector during the management of the coffee by-products to improve the management of coffee by-products and to obtain a material with low emissions to be used afterwards in the coffee plantations as a fertilizer.

Acknowledgments Open Access funding provided by Projekt DEAL. We acknowledge the support, funding, and assistance of this work by the Coffee Mill Cooperatarrazú R.L in Costa Rica. We gladly thank the composting plant facility Abfallwirtschaftbetrieb Landkreis Böblingen as well as the personnel, laboratory assistances, students, and colleagues of the Institute for Sanitary Engineering, Water Quality and Solid Waste Management (ISWA) at the University of Stuttgart.

Open Access This article is licensed under a Creative Commons Attribution 4.0 International License, which permits use, sharing, adaptation, distribution and reproduction in any medium or format, as long as you give appropriate credit to the original author(s) and the source, provide a link to the Creative Commons licence, and indicate if changes were made. The images or other third party material in this article are included in the article's Creative Commons licence, unless indicated otherwise in a credit line to the material. If material is not included in the article's Creative Commons licence and your intended use is not permitted by statutory regulation or exceeds the permitted use, you will need to obtain permission directly from the copyright holder. To view a copy of this licence, visit http://creativecommons.org/licenses/by/4.0/.

\section{References}

Ahn HK, Mulbry W, White JW, Kondrad SL (2011) Pile mixing increases greenhouse gas emissions during composting of dairy manure. Bioresour Technol 102:2904-2909. https://doi.org/10.1016/j. biortech.2010.10.142

Amlinger F, Peyr S, Cuhls C (2008) Greenhouse gas emissions from composting and mechanical biological treatment. Waste Manag Res 26(1):47-60. https://doi.org/10.1177/0734242X07088432

Artola A, Barrena R, Colón J, Segura XF (2015) Composting of wastes decreasing the impact of abandoned mines on water bodies. View project MSW characterization View project. In: Resource Recovery to Approach Zero Municipal Waste. https://doi.org/10.1201/ b18680-6

BGK (2017). Qualitätsmanagement-Handbuch (QMH), RALGütesicherung Kompost (RAL-GZ 251). In B. G. K. (RAL-G. 251) BGK- Bundesgütegemeinschaft Kompost e.V. (Ed.), QMHandbuch Kompost (p. 45). Köln: BGK- Bundesgütegemeinschaft Kompost e.V

Bidlingmaier W (2003). Methods book for the analysis of compost. Germany. Retrieved from https://www.kompost.de/fileadmin/docs/ shop/Grundlagen_GS/Methods_Book_2002.pdf

Blinová L, Sirotiak M, Bartošová A, Soldán M (2017) Review: Utilization of waste from coffee production (Vol. 25), Bratislava. https://doi.org/10.1515/rput-2017-0011

Burg P, Zemánek P, Michálek M (2011). Evaluating of selected parameters of composting process by composting of grape pomace. Acta Universitatis Agriculturae et Silviculturae Mendelianae Brunensis, LIX(6), 75-80. Retrieved from https://acta.mendelu.cz/media/pdf/ actaun_2011059060075.pdf

Bachert CWB, Wattanachira S (2008). Open windrow composting manual. (Werner. Bidlingmaier, Ed.). Thailand: ORBIT. Retrieved from https://www.orbit-online.net/images/orbit-downloads/5 Literature/5_1_Compost_handbook/en/5 1 01-Handbook-oncomposting-eng.pdf

Clausen AM (2015) Mechanical-biological treatment (MBT) processes in consequential carbon footprint modelling of residual municipal solid waste (rMSW) treatment. Shaker, Aachen Retrieved from http:// www.iar.rwth-aachen.de/cms/IAR/Forschung/Publikationen/ eeds/ Einzelansicht $/$ lidx $=1 \&$ file=570566Accessed June 2019

Clauß T, Reinelt T, Liebetrau J, Vesenmaier A, Reiser M, Flandorfer C et al (2019) Recommendations for reliable methane emission rate quantification at biogas plants. Deutsches Biomasseforschungszentrum gemeinnützige $\mathrm{GmbH}$, Leipzig

Cornell University (2001) The science and engineering of composting, Cornell University, Ithaca

Diaz LF, De Bertoldi M, Bidlingmaier W, Stentiford E (2007) Stentiford Compost science and technology. Elsevier, Amsterdam

Esquivel P, Jiménez VM (2012) Functional properties of coffee and coffee by-products. Food Res Int 46(2):488-495. https://doi.org/10. 1016/j.foodres.2011.05.028

Federal Compost Quality Assurance Organization (FCQAO) (1994) Methods book for the analysis of compost. Kompost-Information Nr. 230. Budesgutegemeinschaft Kompost e.V. (English translation by W. Bidlingmaier). Univ. of Essen, Germany, p 199

Hao X, BenkeM B (2008). Nitrogen transformation and losses during composting and mitigation strategies. Dynamic Soil, Dynamic Plant, Global Science Books, (1992)

Haug RT (1993) The practical handbook of compost engineering, 1st edn. Lewis publishers, California

Heeger A, Kosińska-Cagnazzo A, Cantergiani E, Andlauer W (2017) Bioactives of coffee cherry pulp and its utilisation for production of cascara beverage. Food Chem 221:969-975. https://doi.org/10. 1016/j.foodchem.2016.11.067

Hou Y, Velthof GL, Lesschen JP, Staritsky IG, Oenema O (2017) Nutrient recovery and emissions of Ammonia, nitrous oxide, and methane from animal manure in Europe: effects of manure treatment technologies. Environ Sci Technol 51(1):375-383. https://doi.org/10.1021/ acs.est.6b04524

Hrad M, Binner E, Piringer M, Huber-Humer M (2014) Quantification of methane emissions from full-scale open windrow composting of biowaste using an inverse dispersion technique. Waste Manag 34(12):2445-2453. https://doi.org/10.1016/J.WASMAN.2014.08. 013

Iriondo-DeHond A, Aparicio García N, Fernandez-Gomez B, GuisantesBatan E, Velázquez Escobar F, Blanch GP et al (2019) Validation of coffee by-products as novel food ingredients. Innovative Food Sci 
Emerg Technol 51:194-204. https://doi.org/10.1016/J.IFSET.2018. 06.010

Jenkins J (2011). Sanitation by composting. United States. Retrieved from https://humanurehandbook.com/downloads/Compost_ Sanitation Paper 9 2011.pdf

Kranert M (2017) Einführung in die Kreislaufwirtschaft : Planung - Recht - Verfahren. Springer Vieweg, Wiesbaden. https://doi.org/10.1007/ 9783834822574

Lardé G (1989) Investigation on some factors affecting larval growth in a coffee-pulp bed. Biol Wastes 30(1):11-19. https://doi.org/10.1016/ 0269-7483(89)90139-0

Msunar N (2009). The process and pathogen behaviour in composting: a review. Malaysia. Retrieved from https://arxiv.org/ftp/arxiv/papers/ 1404/1404.5210.pdf

Bueno P, Tapias R, López F, M. J. D. (2007) Optimizing composting parameters for nitrogen conservation in composting. Bioresour Technol 99:5069-5077. https://doi.org/10.1016/j.biortech.2007.08. 087

Phong NT, Cuhls C (2016) The effect of turning frequency on methane generation during composting of anaerobic digestion material. $8(1)$ : 50-55. https://doi.org/10.13141/jve.vol8.nol.pp50-55

Misra RV, Roy NR Hiraoka H (2003). On- farm composting methods. Rome. Retrieved from http://www.fao.org/3/a-y5104e.pdf

Rahn E, Läderach P, Baca M, Cressy C, Schroth G, Malin D et al (2014) Climate change adaptation, mitigation and livelihood benefits in coffee production: where are the synergies? Mitig Adapt Strateg Glob Chang 19(8):1119-1137. https://doi.org/10.1007/s11027013-9467-x

San Martin Ruiz M, Reiser M, Hafner G, Kranert M (2018) A study about methane emissions from different composting systems for coffee byproducts on Costa Rica. Environ Ecol Res 6(5):461-470. https://doi. org/10.13189/eer.2018.060506

Sánchez A, Artola A, Font X, Gea T, Barrena R, Gabriel D et al (2015) Greenhouse gas from organic waste composting: emissions and measurements. In: $\mathrm{CO} 2$ Sequestration, Biofuels and Depollution, vol 5. Springer, Spain, pp 33-43. https://doi.org/10.1007/978-3319-11906-9

Sierra CA, Malghani S, Loescher HW (2017) Interactions among temperature, moisture, and oxygen concentrations in controlling decomposition rates in a boreal forest soil. Biogeosciences 14:703-710. https://doi.org/10.5194/bg-14-703-2017

Sun X, Lu P, Jiang T, Schuchardt F, Li G (2014) Influence of bulking agents on $\mathrm{CH} 4, \mathrm{~N} 2 \mathrm{O}$, and $\mathrm{NH} 3$ emissions during rapid composting of pig manure from the Chinese Ganqinfen system *
Xiang-ping SUN $\uparrow 1$. J Zhejiang Univ-Sci B (Biomed \& Biotechnol) 15(4):353-364. https://doi.org/10.1631/jzus.B13a0271

Sundberg C (2008) Improving compost process efficiency by controlling aeration. In: Temperature and $\mathrm{pH}$ Bioresource Technology (Vol Swedish Un). https://doi.org/10.1016/j.biortech.2008.02.014

Sundberg C, Yu D, Franke-Whittle I, Kauppi S, Smärs S, Insam H et al (2013) Effects of $\mathrm{pH}$ and microbial composition on odour in food waste composting. Waste Manag 33(1):204-211. https://doi.org/10. 1016/J.WASMAN.2012.09.017

Nieters A, Grabs J, Jimenez G (GIZ), Alpizar W (DCC) (2015) National Appropiate Mitigation Actions (NAMA) Café Costa Rica - A Tool for Low-Carbon Development. Published by NAMA Facility Technical Support Unit on behalf of German Federal Ministry for the Environment, Nature Conservation, Building and Nuclear Safety (BMUB)/ UK Department for Energy and Climate Change (DECC) In cooperation with: Dirección de Cambio Climático (DCC). https:// www.namacafe.org/sites/default/files/files/NAMA_Facility_ factsheet_Costa\%20Rica.pdf. Accessed July 2019

VDI 3475 part 2 (2005). Emissionsminderung Biologische Abfallbehandlungsanlagen Kompostierung und (Co-)Vergärung Anlagenkapazität bis ca. $6000 \mathrm{Mg} /$ a -Emission control Facilities for biological waste Composting an anaerobic (co-)digestion Plant capacities up to approx. $6000 \mathrm{Mg} / \mathrm{a}$ A. Germany

VDI 3475 part 3 (2006). Emissionsminderung anlagen zur mechanischbiologischen Behandlung von Siedlungsabfällen- emission control Mechnical-biological treatment facilities for municipal solid waste. Germany

VDI 3575 part 1 (2003). Emissionsminderung Biologische Abfallbehandlungsanlagen - Kompostierung und Vergärung Anlagenkapazität mehr als ca. $6.000 \mathrm{Mg} / \mathrm{a}$-Emission control Biological waste treatment facilities Composting and anaerobic digestion Plant capacities more than approx. 6. Germany

Zarrinbakhsh N, Wang T, Rodriguez-Uribe A, Misra M, Mohanty AK (2016) Characterization of wastes and coproducts from the coffee industry for composite material production. BioResources 11(3): 7637-7653. https://doi.org/10.15376/biores.11.3.7637-7653

Zhu-Barker X, Bailey SK, Paw UKT, Burger M, Horwath WR (2017) Greenhouse gas emissions from green waste composting windrow. Waste Manag 59:70-79. https://doi.org/10.1016/j.wasman.2016.10.004

Publisher's note Springer Nature remains neutral with regard to jurisdictional claims in published maps and institutional affiliations. 